\title{
Distribution and recycling of canopy nitrogen storage reserves in sweet cherry (Prunus avium) fruiting branches following 15N-urea foliar applications after harvest
}

\author{
Marlene Ayala, Pilar Bañados, Mariana Thielemann, and Román Toro \\ Facultad de Agronomía e Ingeniería Forestal, Pontificia Universidad Católica de Chile. Vicuña Mackenna \\ 4860, Macul, Santiago, Chile.
}

\begin{abstract}
M. Ayala, P. Bañados, M. Thielemann, and R. Toro. 2014. Distribution and recycling of canopy nitrogen storage reserves in sweet cherry (Prunus avium) fruiting branches following ${ }^{15} \mathrm{~N}$-urea foliar applications after harvest. Cien. Inv. Agr. 41(1): 71-80. In sweet cherries, accumulated nitrogen $(\mathrm{N})$ stores from the previous fall support early spring growth. To complement the $\mathrm{N}$ supply in the soil, Chilean growers use foliar urea applications after harvest. Information on the effectiveness of foliar $\mathrm{N}$ applications in sweet cherry is lacking. To study the canopy distribution of $\mathrm{N}$ applied as urea foliar sprays, an experiment using a "Bing"/"Gisela ${ }^{\circledR}$ " ("GI $\left.₫ 6 "\right)$ sweet cherry orchard was carried out in 2009/2010 in Chile ( $35^{\circ}$ $09^{\prime} 53^{\prime \prime} \mathrm{S}, 71^{\circ} 20^{\prime} 43^{\prime}$ " W). The objective was to investigate $\mathrm{N}$ distribution and recycling in 3 -year-old fruiting branches. A total of 120 branches (one per tree) were labeled using ${ }^{15} \mathrm{~N}$-urea. ${ }^{15} \mathrm{~N}$-urea was applied to the whole branch on four separate dates or treatments (TR) after fruit harvest: $\mathrm{TR}_{1}=\mathrm{Jan}, \mathrm{TR}_{2}=\mathrm{Feb}, \mathrm{TR}_{3}=$ Mar and $\mathrm{TR}_{4}=\mathrm{Apr}$. For each $\mathrm{TR}$, a group of ${ }^{15} \mathrm{~N}$-labeled branches (10 replications) was destructively harvested at 3 times/stages: 15 days after the urea foliar application (DAA), dormancy and stage I of fruit development. Branches were divided into the various organs, dried $\left(70{ }^{\circ} \mathrm{C}\right)$, ground and processed for GC-MS analysis. In all TR, labeled urea was taken up by the leaves and translocated to various organs. The highest $\mathrm{N}$ levels were observed in the fruiting section. $\mathrm{TR}_{1}$ exhibited the highest $\mathrm{N}$ use efficiency (NUE\%). Buds and bark showed the highest $\mathrm{N}$ derived from fertilizer (NDDF\%) values. In all TR, stored $\mathrm{N}$ was recovered in the flowers, immature fruits and young leaves during the following spring. According to the results, urea sprays after fruit harvest constitute an alternative to complementing the $\mathrm{N}$ supply in the soil in sweet cherry trees using "GI®6."
\end{abstract}

Key words: bark, buds, canopy, leaves, $\mathrm{N}$ use efficiency, fruit, stored N, spur, sweet cherry wood.

\section{Introduction}

In sweet cherry (Prunus avium L.), bloom and fruit set heavily depend on carbon (C) and ni-

Received October 8, 2013. Accepted March 27, 2014.

Corresponding author: mayalaz@uc.cl trogen $(\mathrm{N})$ storage reserves accumulated during the previous season after fruit harvest (Neilsen et al., 1997; Lang, 2002; Ayala 2004; Lang, 2005). It has been reported that the remobilization of $\mathrm{N}$ reserves from storage organs (roots, wood, bark and buds) begins just after bud break and that $\mathrm{N}$ 
root absorption begins three weeks later, indicating a dependence on the $\mathrm{N}$ reserves early in the season (Grassi et al., 2002; Grassi et al., 2003; Ouzounis and Lang, 2011). N storage reserves represent approximately $50 \%$ of the $\mathrm{N}$ used for new growth during early spring. The remaining $\mathrm{N}$ comes from root absorption and soil uptake (Grassi et al., 2002; Grassi et al., 2003; Azarenko and Chozinski, 2005).

Dependence on $\mathrm{N}$ reserves is critical for sweet cherry dwarfing combinations because smaller trees develop reduced woody structures (Lang, 2002; Lang, 2005). Soil N applications after harvest improve the accumulation of storage reserves in aerial organs, such as buds, stems and roots (Azarenko and Chozinski, 2005), but the timing is critical. In apple (Malus domestica Borhk.) and pear (Pyrus communis L.) trees, $\mathrm{N}$ applications to the soil after harvest were less effective in terms of the absorption and recovery of the fertilizer than were foliar applications (Shim et al., 1972; Shim et al., 1973; Kang and Titus, 1980; Sanchez et al., 1990). In sweet cherry, Gil (2000) reported a higher $\mathrm{N}$ uptake from leaves compared to roots.

In Chile, sweet cherry nutrition programs recommend applying $\mathrm{N}$ to the soil as the main source, although postharvest foliar applications are becoming increasingly important for highly productive dwarfing combinations. However, the benefit of $\mathrm{N}$ foliar applications in sweet cherries is unknown, and most information comes from other tree fruit species (Shim et al., 1972; Shim et al., 1973; Sanchez et al., 1990; Curetti et.al., 2013). Urea $\left[\mathrm{CO}\left(\mathrm{NH}_{2}\right)_{2} ; 46 \% \mathrm{~N}\right]$ is one of the sources used during foliar applications of $\mathrm{N}$. Urea is water soluble and nonpolar, facilitating its absorption through the leaves (Gil, 2006).

Considering the lack of information on the effectiveness of urea foliar applications in sweet cherry dwarfing combinations, this study focused on foliar sprays of ${ }^{15} \mathrm{~N}$-urea, simulating commercial applications at various times after fruit harvest.
The research hypothesis was that the timing of the urea foliar application might influence the differential uptake and distribution of $\mathrm{N}$ in the fruiting branches of the semi-dwarfing sweet cherry combination "Bing"/“"GI ${ }^{\circledR} 6$."

\section{Materials and methods}

The study was carried out in a 5-year-old "Bing"/“GI ${ }^{\circledR} 6$ " sweet cherry orchard, located in Itahue, Region VII, Chile ( $35^{\circ} 09^{\prime} 53^{\prime}$ ' S, $71^{\circ} 20^{\prime}$ $43^{\prime \prime} \mathrm{W}$ ). The orchard was trained in a central axis pattern and planted at $5.0 \times 3.0 \mathrm{~m}$. The trees were under drip irrigation. The soil type was a sandy-clay.

A completely randomized block design was used for the experiment. From a population of three hundred trees, one-hundred and twenty 3-yearold branches (one per tree) of uniform length, spur number, shoot number, leaf area (LA) and basal diameter were chosen randomly (Figure 1). Each 3-year-old branch included fruiting spurs (growth 2006/2007), non-fruiting spurs (2007/2008) and terminal current season shoot (growth 2008/2009) (Figure 1) leaf populations, without lateral extension shoots.

Trees were sprayed with unlabeled urea at various dates after fruit harvest $\left(\mathrm{TR}_{1}=\mathrm{Jan}, \mathrm{TR}_{2}=\mathrm{Feb}\right.$, $\mathrm{TR}_{3}=$ Mar and $\mathrm{TR}_{4}=\mathrm{Apr}$ ). Prior to the application, one 3-year-old branch was bagged to isolate it from the rest of the tree and then sprayed with a solution of ${ }^{15} \mathrm{~N}$-urea ( $1.8 \%$ atom; at $2 \%$ conc.) Each application date was considered a treatment (TR): $\mathrm{TR}_{1}=\mathrm{Jan}, \mathrm{TR}_{2}=\mathrm{Feb}, \mathrm{TR}_{3}=$ Mar and $\mathrm{TR}_{4}=$ Apr. Thirty branches (replications), one per tree, were labeled with ${ }^{15} \mathrm{~N}$-urea per TR. A total of 10 branches per tree were harvested 15 days after foliar urea application (DAA); 10 branches were harvested during dormancy (Jul, 2010); and 10 branches were harvested during early spring (stage I of fruit development, Sep, 2010) for each TR. Additional branches (36 units) were used to carry out natural abundance measurements. 


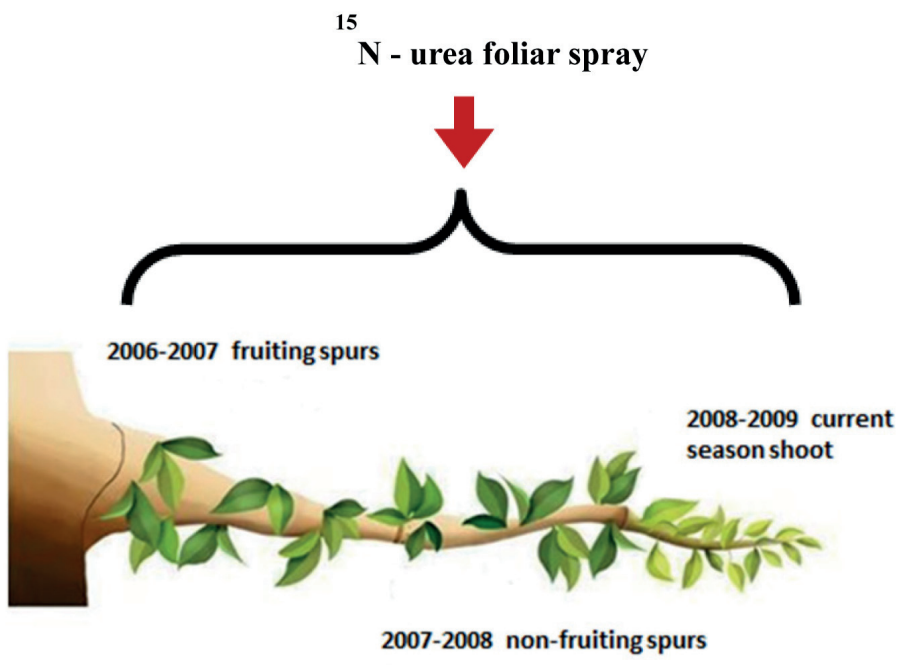

Figure 1. Three-year-old sweet cherry (Prunus avium L.) branch illustrating three growing sections without lateral extension shoots: 2006/2007 (fruiting spur section); 2007/2008 (non-fruiting spur section); and 2008/2009 (current season shoot section).

The urea foliar applications (labeled and unlabeled) were made within a $24 \mathrm{~h}$ period but divided into two applications on two consecutive days, with one evening (day 1) and one morning (day 2) application. A $1 \mathrm{~L}$ manual knapsack sprayer was used to apply the ${ }^{15} \mathrm{~N}$-urea solution to individual branches. Run-off from the trees and individual branches was recovered using paper sheets placed on a semi-cylindrical metal frame. ${ }^{15} \mathrm{~N}$-enriched branches were removed and divided into leaves, buds, bark, wood, roots and fruit during each developmental stage of sampling. Organs/tissues were dried in an oven (model AD $810 \mathrm{~L}$ ) at $70^{\circ} \mathrm{C}$. Later, organs/tissues were ground and prepared for mass spectrometry analysis (GC-MS, model “20-20”).

The nitrogen derived from fertilizer (NDFF \%), nitrogen derived from fertilizer in $\mathrm{mg}$ (NDFF $\mathrm{mg}$ ) and nitrogen use efficiency (NUE \%) were calculated according to widely used formulas (IAEA, 1976; Hauck and Bremner, 1976; Millard and Nielsen, 1989; Pino et al., 2006).

Statistical analysis was performed using the module PROC MIXED in SAS ${ }^{\circledR} 9.1$ (SAS Institute Inc., Cary, NC, version 8.2).

\section{Results and discussion}

Sweet cherry spur and shoot leaves were able to take up ${ }^{15} \mathrm{~N}$-urea. The highest NDFF \% values from leaves were observed 0 days after urea foliar application, except for TR1. In general, the lowest NDFF\% values were recorded at leaf fall (Figure 2). N uptake by the leaves and translocation has been reported for pear (Sánchez et al., 1990; Curetti et.al., 2013), almond (P. dulcis (Mill.) D.A. Webb.; Youssefi et al., 2000), apple (Shim et al., 1972; Shim et al., 1973) and grape (Vitis vinifera L.) (Porro et al., 2006). Lower NDDF\% values in sweet cherry leaf at leaf fall indicates the translocation of $\mathrm{N}$ compounds to other organs within the branch or out of it after foliar application. The translocation of $\mathrm{N}$ has been reported in sweet cherry (Azarenko et al., 2008; San Martino et al., 2010; Ouzounis and Lang, 2011).

The NUE \% of labeled branches varied depending on the timing of the urea foliar application (TR) and the phenological stage of the plant when the destructive sampling of the branches was performed (15 days after urea foliar application, dormancy and stage I of fruit development). 


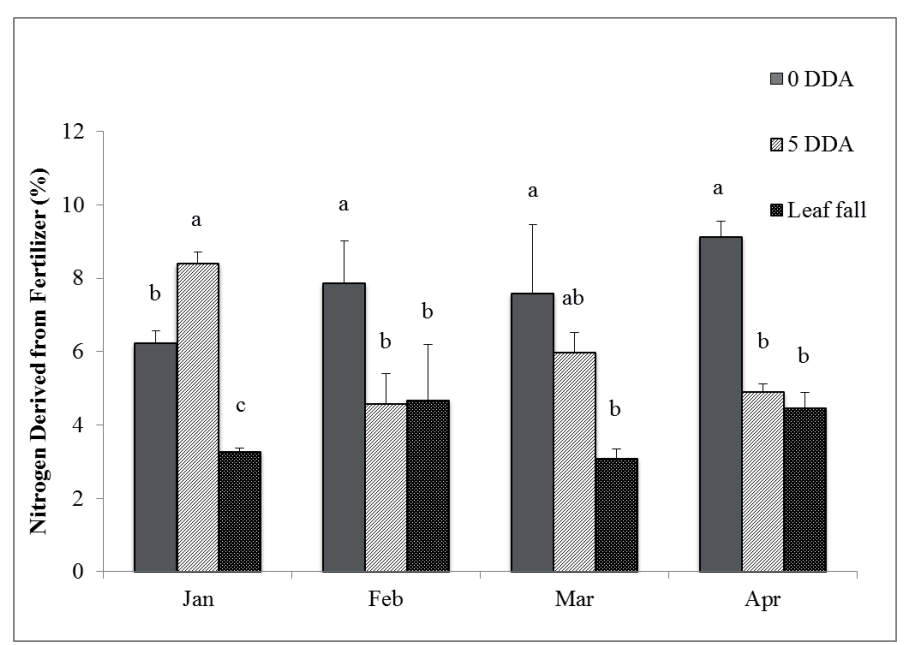

Figure 2. Percentage of nitrogen derived from fertilizer (NDDF \%) in leaves from the combination "Bing"/"Gisela ${ }^{\circledR} 6$," sampled 0 or 5 days after foliar urea application (DAA) and leaf fall (Jun) for four timings of ${ }^{15} \mathrm{~N}$-urea foliar applications $\left(\mathrm{TR}_{1}=\mathrm{Jan}, \mathrm{TR}_{2}=\mathrm{Feb}, \mathrm{TR}_{3}=\mathrm{Mar}\right.$ and $\left.\mathrm{TR}_{4}=\mathrm{Apr}\right)$. Bars with the same letter for the same month are not significantly different $(\alpha=0.05)$. DAA: days after foliar urea application.

The longer the delay between ${ }^{15} \mathrm{~N}$-urea spray and harvest, the lower the NUE\% observed at each sampling date. A lower NUE\% may be related to reduced leaf metabolic activity and leaf age. Leaves were physiologically less senescent in Jan than in Apr, particularly current season shoot leaves (i.e., sylleptic shoots). In sweet cherry, fruiting and non-fruiting spur leaves become fully mature approximately 20 to 30 days after bloom, whereas extension shoots continue developing new leaves after harvest. As the growing season progressed, the leaves of spurs and shoots become older and less efficient. It is likely that the lower NUE\% values observed late in the season were the result of leaf senescence (Table 1).

Table 1. Nitrogen use efficiency (\%) for four dates of ${ }^{15} \mathrm{~N}$ urea foliar applications to "Bing"/"Gisela $₫ 6 "\left(\mathrm{TR}_{1}=\right.$ January, $\mathrm{TR}_{2}=$ February, $\mathrm{TR}_{3}=$ March and $\mathrm{TR}_{4}=$ April) and three rounds of destructive branch removal (15 days after application, dormancy and stage I of fruit development). Columns with the same letter are not significantly different $(\alpha=0.05)$. DAA: days after foliar urea application.

\begin{tabular}{lccc}
\hline Month & 15DAA & Winter (Jul) & Spring (Oct) \\
\hline Jan & $25.0 \mathrm{a}$ & $20.4 \mathrm{a}$ & $17.1 \mathrm{a}$ \\
Feb & $19.2 \mathrm{ab}$ & $10.4 \mathrm{~b}$ & $13.7 \mathrm{~b}$ \\
Mar & $14.4 \mathrm{~b}$ & $9.0 \mathrm{~b}$ & $12.2 \mathrm{~b}$ \\
Apr & $10.8 \mathrm{c}$ & $7.9 \mathrm{c}$ & $6.5 \mathrm{c}$ \\
p-value & 0.0025 & 0.0012 & 0.0001 \\
\hline
\end{tabular}

When labeled branches were removed 15 days after urea foliar application, significant differences were observed among TRs. At that time, $\mathrm{TR}_{1}$ had the highest NUE\% and $\mathrm{TR}_{4}$ had the lowest value for this parameter. A similar trend was observed when labeled branches were removed during dormancy and stage I of fruit development.

In this experiment, NUE ranged between 6.5 to $25.0 \%$ depending on the TR and sampling date. NUE\% was higher following ${ }^{15} \mathrm{~N}$-urea foliar applications close to fruit harvest. In apple (Shim et al., 1972; Shim et al., 1973, Kang and Titus, 1980) and pear (Sánchez et al., 1990) trees, foliar N applications after fruit harvest were more efficient than were soil $\mathrm{N}$ applications. In peach trees $(P$. persica L.), Nario et al. (2003) reported a NUE of $12.7 \%$ for soil applications during the summer. However, Neto et al. (2006) reported a NUE of $6.3 \%$ after $\mathrm{N}$ soil applications in pear trees. These authors used ${ }^{15} \mathrm{~N}$ as a tracer, and the trees were analyzed during dormancy. The highest NUE\% values $(25 \%)$ were recorded in $\mathrm{TR}_{1} 15$ days after urea foliar application. In general, the NUE\% decreased between Jan (soon after fruit harvest) and Apr (leaf fall). The higher NUE\% values in Jan and Feb might be explained by more efficient 
$\mathrm{N}$ uptake by the current season shoot leaves and a higher metabolic activity of the leaves. In addition, other sinks become important soon after fruit harvest, such as the roots and reproductive buds. In the combination "Bing"/“GI@6," a peak in root growth has been observed during Jan and Feb in the Central Valley of Chile, along with active flower bud differentiation (unpublished data Ayala, 2012).

$\mathrm{N}$ translocation was evident during all foliar applications dates. The ${ }^{15} \mathrm{~N}$ contents of the leaves declined until leaf fall (Figure 2). This event coincided with a rise in the levels of ${ }^{15} \mathrm{~N}$ found in the bark, wood and buds, indicating the translocation of ${ }^{15} \mathrm{~N}$ compounds to these organs from the leaves after harvest (Figure 3 and 4). Because the recovery of $\mathrm{N}$ (expressed as NDDF $\mathrm{mg}$ ) in the whole branch was less than the amount initially applied (data not shown), part of the taken-up N was translocated to other storage organs outside the branch, such as the trunk, other branches and root (Figure 4). In this experiment, roots of various sizes were sampled at each branch removal date, but no ${ }^{15} \mathrm{~N}$ enrichment was found in them (data not shown). The roots have been reported as a major
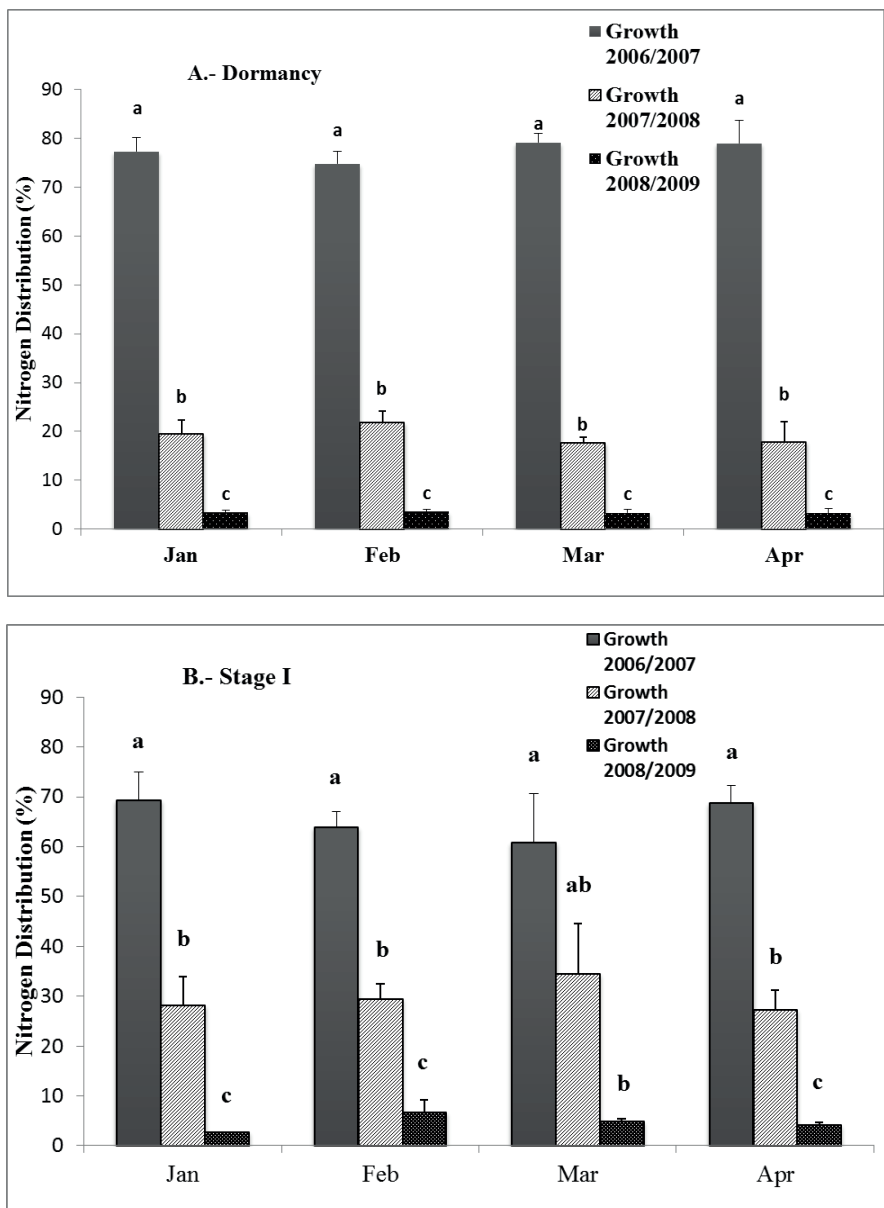

Figure 3. Distribution of nitrogen derived from fertilizer (\%) in 3-year-old branches of "Bing"/“Gisela ${ }^{6} 6$ " sweet cherry from three growing sections: 2006/2007 (fruiting spur section); 2007/2008 (non-fruiting spur section); and 2008/2009 (current season shoot section), as well as after 4 dates of urea foliar application (Jan, Feb, Mar, Apr) and two times (A.- dormancy and B.- stage I of fruit development) with destructive branch removal. Bars with the same letter within the same month are not significantly different $(\alpha=0.05)$. 

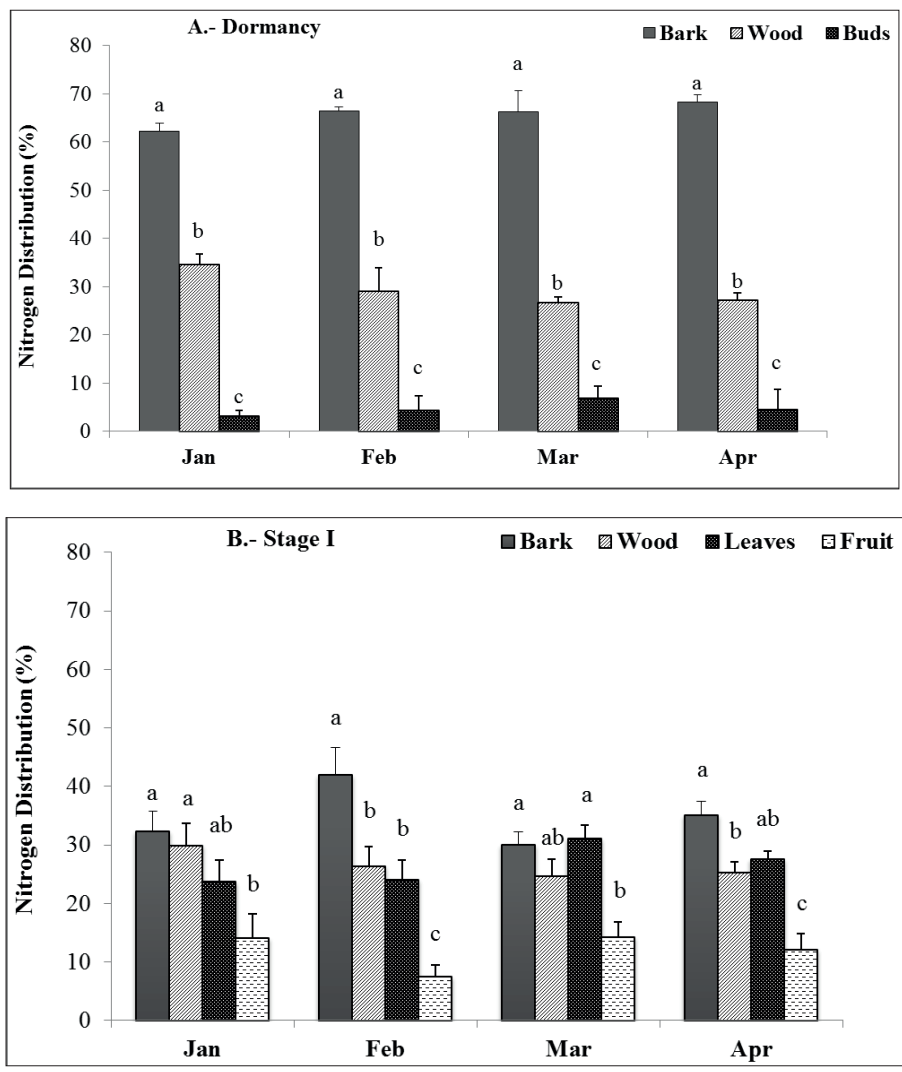

Figure 4. Distribution of nitrogen derived from fertilizer (\%) in the organs of 3-year-old branches of "Bing"/“Gisela ${ }^{6} 6$ " sweet cherry from three growing sections: 2006/2007 (fruiting spur section); 2007/2008 (non-fruiting spur section); and 2008/2009 (current season shoot section) after 4 dates of urea foliar application (Jan, Feb, Mar, Apr). Bars with the same letter within the same month are not significantly different $(\alpha=0.05)$.

storage tissue for sweet cherry by other authors (Loescher et al., 1990; Grassi et al., 2003; Ayala, 2004; Gil, 2006). It is also likely that some of the urea applied was lost due to volatilization (Silva and Rodriguez, 1995).

A differential $\mathrm{N}$ distribution within labeled branches was observed depending on the timing of the foliar spray (Jan, Feb, Mar and Apr), the growth period $(2006 / 2007 ; 2007 / 2008$, and $2008 / 2009$ ) and the phenological stage (15 days after application, dormancy and stage I of fruit development) at the time of branch removal (Fig 3). During dormancy, significant differences in $\mathrm{N}$ distribution among growth periods were observed for all TRs. Most of the ${ }^{15} \mathrm{~N}$ was recovered from the fruiting spur section (2006/2007 growth), whereas the lowest $\mathrm{N}$ levels were observed in the terminal current season shoots $(2008 / 2009$ sylleptic growth). Additionally, significant differences were detected in the $\mathrm{N}$ levels among organs during dormancy (bark, wood and buds) in all TRs. Bark exhibited the highest $\mathrm{N}$ levels (62 to $68 \%$ of the total recovery), followed by wood ( 27 to $35 \%$ ) and buds (3 to $8 \%$ ). Most of the $\mathrm{N}$ recovered from the fruiting spur section (2006/2007 growth) was in the bark. A similar pattern was observed in branches that were destructively removed during stage I of fruit development. Most of the $\mathrm{N}$ was recovered from the fruiting spur section. However, the $\mathrm{N}$ distribution among organ/tissues was different from the pattern observed during dormancy. In early spring, bark and wood showed a decrease in $\mathrm{N}$ levels following translocation to developing fruit and shoots. 
These results are interesting because it is possible to conclude that in branches of the sweet cherry combination "Bing"/“GI@6," reproductive spurs are a priority sink for $\mathrm{N}$ partitioning. Most of the $\mathrm{N}$ was translocated and accumulated in the fruiting spurs section to be remobilized into flowers, immature fruits and young leaves early in the spring, indicating that the $\mathrm{N}$ derived from foliar applications is not only taken up by the leaves and translocated to other organs but is also remobilized during the spring to promote budbreak, bloom and initial fruit development.

Therefore, the leaves of 3-year-old sweet cherry branches were able to take up foliar $\mathrm{N}$ supplied as ${ }^{15} \mathrm{~N}$-urea after fruit harvest. $\mathrm{N}$ was translocated basipetally to various tissues/organs of the branch. The buds and bark registered the highest NDFF\%, indicating a higher sink activity of these organs compared with wood. The highest $\mathrm{N}$ levels (expressed as NDFF mg) were found in the bark of the fruiting spur section for all dates evaluated. These results indicate that the fruiting spur section of the branch has the highest sink strength for $\mathrm{N}$ after harvest.

$\mathrm{N}$ foliar applications provided soon after fruit harvest (Jan) resulted in the highest NUE\%. This high NUE \% might be explained by the need for $\mathrm{N}$ during flower bud differentiation and/or a more efficient foliar $\mathrm{N}$ uptake by the current season shoot leaves, which are younger and thicker than the spur leaves and have a greater capacity to take up $\mathrm{N}$.

In all TRs, the stored $\mathrm{N}$ was recovered in immature fruits and young leaves the following spring. Accordingly, urea sprays after fruit harvest might constitute an alternative to complement the $\mathrm{N}$ supply from the soil in sweet cherry combination "Bing"/“GI®6." Further studies are needed to evaluate whether postharvest foliar urea should be applied multiple times and whether a similar pattern of $\mathrm{N}$ partitioning can be observed in other highly productive scion/rootstock combinations.

\section{Resumen}

M. Ayala, P. Bañados, M. Thielemann y R. Toro. 2014. Distribución de reservas aéreas de nitrógeno en ramas de cerezo dulce (Prunus avium) después de una aplicación foliar de ${ }^{15} \mathrm{~N}$-urea. Cien. Inv. Agr. 41(1): 71-80. En cerezo dulce, el nitrógeno $(\mathrm{N})$ de almacenaje es acumulado en otoño previo a la cosecha. Productores chilenos usan urea foliar después de cosecha, pero la información disponible sobre de la efectividad de estas aplicaciones, en combinaciones enanizantes de cerezo dulce, es escasa. Por esta razón, en la temporada 2009/2010 se realizó un experimento para estudiar la distribución de $\mathrm{N}$ aplicado como urea foliar, utilizando la combinación "Bing”/“Gisela ${ }^{\circledR} 6 "$ ("GI $\left.{ }^{\circledR} 6 ”\right)$. Un total de 120 ramas fueron enriquecidas con ${ }^{15} \mathrm{~N}$-urea, la cual fue aplicada en cuatro fechas distintas (Tratamientos; $\mathrm{TR}$ ) después de la cosecha: $\mathrm{TR}_{1}=$ Ene, $\mathrm{TR}_{2}=\mathrm{Feb}, \mathrm{TR}_{3}=\mathrm{Mar}$ and $\mathrm{TR}_{4}=\mathrm{Abr}$. En cada $\mathrm{TR}, 10$ ramas enriquecidas con ${ }^{15} \mathrm{~N}$ - fue removida destructivamente en tres estados fenológicos: 15 días después de la aplicación (15 DDA), dormancia y fase I de desarrollo del fruto. Ramas individuales fueron divididas en diferentes órganos/tejidos, y procesadas para análisis, usando GC-MS. ${ }^{15} \mathrm{~N}$-urea fueron absorbida por las hojas y translocada a los distintos órganos. El contenido más alto de $\mathrm{N}$ se registró en la sección frutal. $\mathrm{TR}_{1}$ registró la mayor eficiencia de uso del fertilizante. Yemas y corteza obtuvieron los mayores valores de nitrógeno derivado del fertilizante. En todos los tratamientos, el $\mathrm{N}$ almacenado fue remobilizado hacia flores, frutos inmaduros y hojas jóvenes. Los resultados indican que aplicaciones foliares de urea pueden complementar aplicaciones de $\mathrm{N}$ al suelo en la combinación "Bing”/“"GI ${ }^{\circledR} 6 "$.

Palabras clave: Corteza, dardos, dosel, eficiencia de uso del nitrógeno, frutos, hojas, madera de cerezo dulce, nitrógeno de almacenaje, yemas. 


\section{References}

Ayala, M. 2004. Carbon partitioning in sweet cherry (Prunus avium L.) on dwarfing precocious rootstocks during fruit development. Ph.D. Thesis. Michigan State University. United States.

Azarenko, A. and A. Chozinski. 2005. Timing of nitrogen application influences the efficiency of nitrogen uptake. In: Whiting, M.D. (ed.) 2005. Producing Premium Cherries. Pacific Northwest Fruit School Cherry Shortcourse Proceedings. p. 85-88.

Curetti M., E. Sánchez, M. Tagliavini, and P. Gioacchini. 2013. Foliar-applied urea at bloom improves early fruit growth and nitrogen status of spur leaves in pear trees, cv. Williams Bon Chretien. Scientia Holticulturae 150:16-21.

IAEA- International Atomic Energy Agency. 1976. Tracer manual on the crops and soils. Technical Report series No. 171. International Atomic Energy Agency (IAEA) of the United Nations, Vienna, Austria.

Gil, G. 2000. Fruticultura: El Potencial Productivo y La Producción de Fruta. Volúmenes 1 y 2. Ediciones Universidad Católica. Santiago, Chile. $342 \mathrm{pp}$.

Grassi, G., P. Millard, R. Wendler, G. Minotta, and M. Tagliavini. 2002. Measurement of xylem sap amino acid concentrations in conjunction with whole tree transpiration estimates spring $\mathrm{N}$ remobilization by cherry (Prunus avium L.) trees. Plant, Cell and Environ. 25:1689-1699.

Grassi, G., P. Millard, P. Gioacchini, and M. Tagliavini. 2003. Recycling of nitrogen in the xylem of Prunus avium trees starts when spring remobilization of internal reserves declines. Tree Physiol. 23:1061-1068.

Hauck, R., and Bremner, J. 1976. Use of tracers for soil and fertilizer nitrogen research. Advances in Agronomy 28:219-266.

Kang, S., and J. Titus. 1980. Qualitative and quantitative changes in nitrogeneous compounds in senescing leaf and bark tissues of the apple. Physiol. Plant 50:285-290

Lang, G. 2002. Sistemas Intensivos de Producción de Cereza. Portainjertos, Vigor, Precocidad, Pro- ductividad y Manejo. Instituto de Investigaciones Agropecuarias, Centro Regional de Investigacion Tamel Aike. Coyhaique, Chile. Serie Actas - Instituto de Investigaciones Agropecuarias $N^{\circ}$ 18. p. 169-191.

Lang, G. 2005. Underlying principles of high density sweet cherry production. Acta Hort. 667:325333.

Loescher, W., T. McCamant, and J. Keller. 1990. Carbohydrate reserves, translocation and storage in woody plant roots. HortScience 25: 274-281.

Nario, A., I. Pino, F. Zapata, M. Albornoz, and P. Baherle. 2003. Nitrogen (15N) fertiliser use efficiency in peach (Prunus persica L.) cv. Goldencrest trees in Chile. Scientia Hortic. 97:279-287.

Neilsen, D., P. Millard, G. Neilsen, and E. Hogue. 1997. Sources of $\mathrm{N}$ for leaf growth in a high density apple (Malus domestica) orchard irrigated with ammonium nitrate solution. Tree Physiol. 17:733-739.

Neto, C., C. Carranca, A. de Varennes, C. Oliveira, J. Clemente, and J. Sobreiro. 2006. Nitrogen use efficiency of drip-irrigated "Rocha" pear trees. Acta Hort. 721:337-342.

Pino, I., A. Parada, A. Nario, and X. Videla. 2006. Técnicas isotópicas aplicadas a los estudios de suelo y plantas. p: 309-352. In: Luzio, W. and M. Casanova (eds.). Avances en el conocimiento de los suelos de Chile. Santiago, Chile. 393 pp.

Porro, D., C. Dorigatti, M. Stefanini, and M. Policarpo. 2006. Foliar nitrogen composition and application timing influences nitrogen uptake by, as well as partitioning within, two grapevine cultivars. Acta Hort. 721:245-250.

Sánchez, E., T. Righetti, D. Sugar, and P. Lombard. 1990. Response of "Comice" pear trees to postharvest urea spray. J. Hortic. Sci. 65: 541-546

San-Martino, L., G. Sozzi, S. San-Martino, and R. Lavado. 2010. Isotopically-labelled nitrogen uptake and partitioning in sweet cherry as influenced by timing of fertilizer application. Scientia Hort. 126:42-49.

Shim, K., J. Titus, and W. Splittstoesser. 1972. The utilization of post-harvest urea sprays by senescing apple leaves. J. Amer. Soc. Hort. Sci. 97:592596. 
Shim, K., J. Titus, and W. Splittstoesser. 1973. The fate of carbon and nitrogen form urea applied to foliage of senescing apple trees. J. Amer. Soc. Hort. Sci. 98:360-366.

Silva, H., and J. Rodríguez. 1995. Fertilización de Plantaciones Frutales. Ediciones Universidad Católica. Santiago, Chile. 519 pp.
Youseffi, F., S. Weinbaum, and P. Brown. 2000. Regulation of nitrogen portioning in field-grown almond trees: Effects of fruit load and foliar nitrogen applications. Plant and Soil 227:273-281.

Wojcik, P. 2004. Uptake of mineral nutrients from foliar fertilization. J. Fruit Orn. Plant Res. 12:201218. 
